\title{
Factors Militating Against Women's Political Participation in Nupe Communities of Central Nigeria
}

\author{
Yahaya Umar, A. G. Umar Kari
}

\begin{abstract}
The study examined factors militating against women's political participation in selected rural and semi-urban, mainly Muslim, Nupe-speaking communities in central Nigeria. Both the social survey and in-depth interviews methods were employed with selected respondents, composed of women leaders, electoral officers, party chieftains and a few female candidates and aspirants for elective positions. The study reveals among other things that,on a scale, women in the area have not been meaningfully involved in politics since the return of democratic rule in 1999, mainly due to poor financial status, divergent socio-cultural challenges and the unfavourable political environment. Accordingly, the study recommends a number of measures to end women subordination, discrimination and stigmatization and improvement in their political participation and fortunes.
\end{abstract}

Index Terms - Women, Politics, Political Participation, Nupe-speaking Communities.

\section{INTRODUCTION}

Women's involvement in politics varies throughout the world and their participation in politics and the democratic process has become an integral part of contemporary discourse on development and governance. In spite of the clamour for women's political empowerment, researches have consistently shown that in many parts of the world women still wallow on the fringes of the political realm and their participation in government structures and the democratic process remains low (Ogbogu, 2011; Vissandjee, et al., 2008).

Historical evidences in many societies, both during the ancient and modern periods, support the idea of male domination over their female folks in many spheres of human endeavour (Awofeso and Odeyemi, 2014). The literature on the subjugation of women to men's domination knows no bound covering wide range of issues, including politics, class and work, the family, globalization, human rights, culture, race and racism, reproduction, science, human trafficking and sexuality (Jimoh, 2014).

Throughout ages and virtually in all cultures, women were rarely considered equal to their male counterparts. From the home as daughter, wife, and mother, through the school,

Yahaya Umar, Department of Sociology, University of Abuja, Nigeria

A. G. Umar Kari, Department of Sociology, University of Abuja, Nigeria office and church as student, employee and worshiper respectively, to the public sphere of life as in business and politics, women are known to have been discriminated, marginalized and dominated through the combination of gender-bias cultural norms and practices which were in favour of men (Akor, 2015).

African societies, including Nigeria, are equally inundated and characterized with several cultural practices which tend to promote male superiority over the female gender. In the case of Nigeria for instance, Enemuo (1999) observed that 'Nigerian communities approve such practices as; preference for male child, payment of bride price, female circumcision or female genital mutilation (FGM), negative attitude towards childlessness, degrading widowhood practices, inheritance practices that discriminate against women and giving away girls in marriage early and without their consent.'

Of more concern is the fact that, over the years, the Nigerian political scene has been characterized by 'patriarchy' which in the words of Heywood (2007) generally connotes rule by men. Although, women were politically active and relatively less exclusive in the decision-making process in many pre-colonial societies, colonial administration with its gender-bias policies helped to enthrone and sustain patriarchy. For instance, women were known to have occupied very influential political offices, including the highest political office (the King or the Oba) among the Yorubas. Female individuals such as the Iyalode of Ibadan, Efunsetan Aniwura, Moremi of Ile-Ife, Queen Amina of Zaria, etc. were powerful political forces who occupied very sensitive positions in the overall political hierarchy of their respective communities. Some of these women performed creditably even as military warlords in their respective communities (Okafor and Akokuwebe, 2015).

However, present-day realities have shown that women are grossly under-represented in public life and decision-making positions. Udegbe (1998), for instance, revealed that women in both elective and appointive positions in Nigeria are less than 7 percent (in Agbalajobi, 2010).

This is in spite of concerns and efforts by national and international organizations, individuals and women's groups. In Nigeria, Section 40 of the 1999 Constitutionprovides that every person shall be entitled to assemble freely and associate with other persons. In particular, the Constitution makes it clear that any citizen, male or female, may form or belong to any political party, trade union or any other association for the protection of his/her interests. The right of women not to be 
discriminated against in terms of participation in any legitimate endeavour is further upheld by the Constitution in Section 42. Furthermore, Nigeria in the year 2006 adopted the National Gender Policy. The goal of the policy was to eliminate all forms of discrimination against women, empowering them through enhanced strategic human resource development, among other things. To this end, mostfourth republic political parties in Nigeria have taken steps to encourage women political participation through affirmative action, including reserving some party offices for them and giving women aspirants nomination forms free of charge.

Several factors have been cited by scholars and researchers as militating against women political participation in Nigeria. According to Nebolisa (2009), they are mainly socio-economic factors (poverty, religious beliefs, cultural values, etc) as well as environmental and even biological factors.

However, most literature and studies on women's political participationin Nigeria tend to focus almost exclusively on the political whys and wherefores of the phenomenon. With specific reference toNupe-speakingcommunities of Niger State, central Nigeria, this study examined the issues from a sociological perspective.

\section{LITERATURE REVIEW}

\section{Women and Political Participation}

Historically, women have been discriminated against either in participation of election of political leaders or emerging as political leaders (Falade, 2014; Igbuzor, 2011). Women all over the world share a common feature of marginalization in all spheres of life. Their number in parliament all over the world is not commensurate with their population.

The situation in Nigeria is not different. The constitutional history of Nigeria shows that this exclusion dates back to the colonial times when women were not allowed to vote. According to the Clifford Constitution of 1922, the electorates were only restricted to the adult males in Calabar and Lagos who were resident in the city for at least one year and had a gross annual income of N100.00. Similarly, Falade (2014) observed that the Richard Constitution of 1946 only reduced the property qualification to N50.00. On the other hand, the Macpherson Constitution removed property qualification but still restricted the electorate to only adult males who paid their taxes. In fact, it was not until 1979 according to Igbuzor (2009), that the right to vote was extended to all Nigerian women. As stated by Igbuzor, while men started voting in Nigeria in 1922, women in all parts of the country started voting in 1979, a difference of 57 years.

The effect of the age-long marginalization of women in different spheres of endeavour has resulted in their low participation in the nation's political process which remained evident till today as can be seen in the Table 2.1 below:

Table 1: Summary of women's representation in elective positions since 1999:

\begin{tabular}{|c|l|l|l|l|l|c|c|c|}
\hline S/ & Position & $\begin{array}{c}\text { No } \\
\text { Available } \\
\text { Seats }\end{array}$ & $\begin{array}{c}\text { No } \\
\text { Women } \\
\mathbf{1 9 9 9}\end{array}$ & $\begin{array}{c}\text { of } \\
\text { in }\end{array}$ & $\begin{array}{c}\text { No of } \\
\text { Women in } \\
\mathbf{2 0 0 3}\end{array}$ & $\begin{array}{c}\text { No of } \\
\text { Women } \\
\text { in 2007 }\end{array}$ & $\begin{array}{c}\text { No of } \\
\text { Women in } \\
\mathbf{2 0 1 1}\end{array}$ & $\begin{array}{c}\text { No of } \\
\text { women } \\
\text { in 2015 }\end{array}$ \\
\hline 1 & Presidency & 2 & 0 & 0 & 0 & 0 & 0 \\
\hline 2 & Senate & 109 & 3 & 4 & 8 & 8 & 7 \\
\hline 3 & House of Reps & 360 & 12 & 23 & 26 & 26 & 19 \\
\hline 4 & Governorship & 36 & 0 & 0 & 0 & 0 & 0 \\
\hline 5 & Deputy Governorship & 36 & 1 & 2 & 6 & 3 & 4 \\
\hline 6 & $\begin{array}{l}36 \text { States Houses of } \\
\text { Assembly }\end{array}$ & 990 & 12 & 38 & 54 & 62 & NA \\
\hline \multicolumn{2}{|l|}{ Total } & 1533 & 28 & 67 & 94 & 99 & \\
\hline
\end{tabular}

\section{Source: Omolara (2015)}

Throughout the world, the power relations that shape social, political, economic and cultural life prevent women from participating fully in all areas of their lives, whether it's in the home, or in the public arena (Makama, 2013). According to IPU (2017), progress in the number of women members of parliament worldwide continues to be slow and that the global average of women in national parliaments increased just slightly from $22.6 \%$ in 2015 to $23.3 \%$ in 2016 .

While women's dedicated efforts to challenge the status quo have allowed more women to reach positions of power in recent years, women continue to be under-represented in all areas of decision-making, such as religion, the media, culture and the law and still face significant barriers to their full and equal participation in the structures and institutions which govern their lives (Omotola, 2007) and (Ajayi, 2007).

Overview of the Status of Women's Political participation in Nigeria

According to Igwe (2002) political involvement (or participation) is the degree and forms of involvement of citizens in governance and related institutions of society such as the economy and culture. It entails the participation of the 
citizenry in political campaigns and debates, attending strategy meetings of political parties, voting during elections, contesting as aspirants for elections and holding of important government and political party positions (Douglas, 2014).

Democracyentails fairness, equal participation and equal treatment of all citizens - male and female in the representation and control of power of a society. Galston (2001) agrees that political participation is good for democracy but he notes that all democracies are plagued by systematic inequalities in participation. In the same vein, according to Hilde \& Catherine (2011), one of the most persistent inequalities has been based on gender such that women are found to participate less than men, which suggests that half of the population's interests are not well represented. Indeed, several scholars have observed complexity and disparity in the relationships between gender and political participation (Henderson, 2006; Anifowose, 2004; Akinboye, 2004; Rai, 2000; Farzana, 2005).

Low participation and representation of women in public and political institutions of several countries have been reported. For instance, Douglas (2014) asserts that gender inequality is prevalent in Kenya as the country ranked 145 out of 186 countries in the 2012 Gender Inequality index. Similarly, Farzana (2005) claims that women's participation in legislatures around the world is 15 percent just as the UNDP (2005) reported that despite the pronounced commitment of the international community to gender equality and to the bridging the gender gap in the formal political arena, reinforced by the Convention on Elimination of All Forms of Discrimination Against Women (CEDAW) and the Beijing Platform of Action, there are only twelve countries where women hold $33 \%$ or more seats in the parliaments. According to the United Nation's (UN) Human Development Reports (2013), Nigeria ranked 152 out of 187 countries and it was classified as a low human development country.

The issue of women's political participation in Nigeria can be best explained by examining the roles played by women effective from the fourth Republic, i.e. from 1999 to date.

\section{Women in the Fourth Republic}

The return of democracy in May 29, 1999 gave hope for a new dawn in the struggle for more participation of women in Nigerian politics. There have been five administrations between 1999 and 2015. President Obasanjo occupied the office of the president between 1999 and 2007, President Umaru Musa Yar`Adua (2007-2010), President Goodluck Jonathan (2010-2015) and President Muhammadu Buhari (2015 to present). Similarly, four males have been President and Vice President within the period.

TheSenate has also been dominated by males. In 1999, there were only 3 women out of the 109 members. In 2003 the number slightly increased to 4 , then jumped to 8 in 2007 , dropped to 7 in 2011, and returned to 8 in 2015.

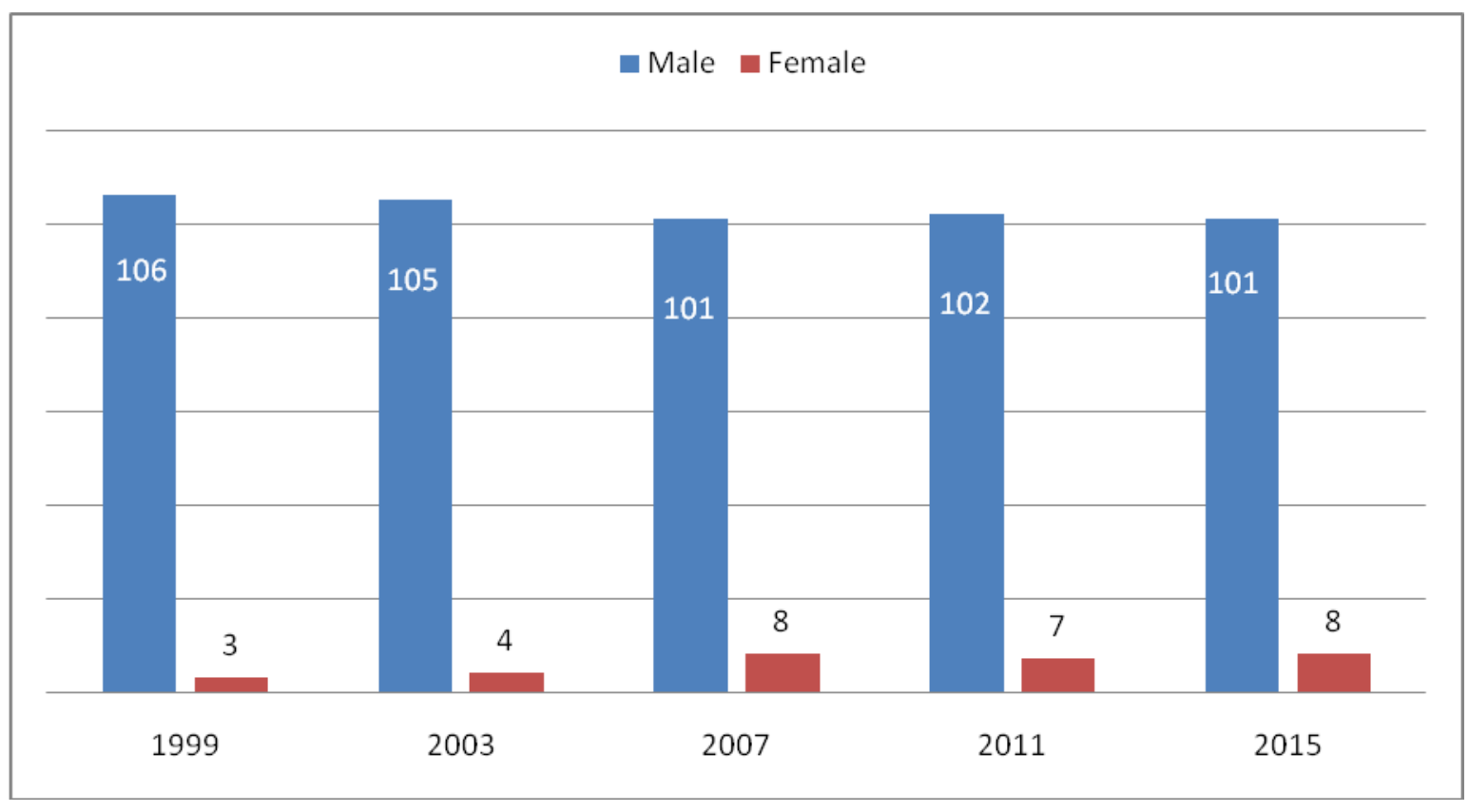

Figure 1: Elected Senators by Sex (1999 - 2015)

\section{Source: NBS Report on Monitoring Participation of Women in Politics in Nigeria (2015)}

In 1999, the number of women in the House of Representatives was 12 out of 360 members, but increased to 21 in 2003. It was 23 in 2007, 26 in 2011, and19 in 2015. 


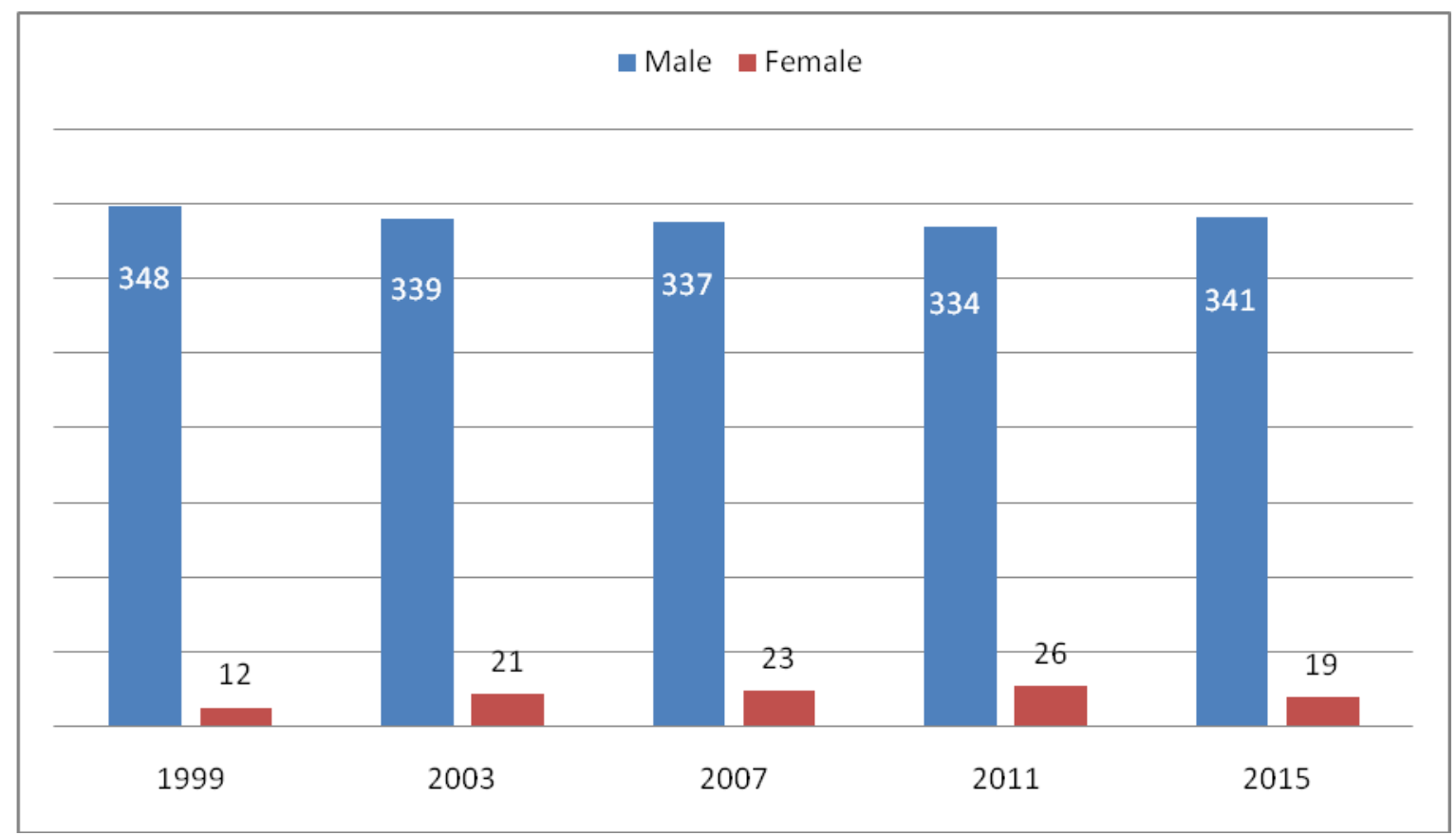

Figure 2: Elected Members of House of Representatives by Sex (1999 - 2015)

Source: NBS Report on Monitoring Participation of Women in Politics in Nigeria, 2015

Table 2: General Elective Positions (1999 - 2015)

\begin{tabular}{|c|c|c|c|c|c|c|c|c|c|c|}
\hline \multirow[b]{2}{*}{ Office } & \multicolumn{2}{|l|}{1999} & \multicolumn{2}{|c|}{2003} & \multicolumn{2}{|l|}{2007} & \multicolumn{2}{|c|}{2011} & \multicolumn{2}{|l|}{2015} \\
\hline & $\begin{array}{l}\text { Seat } \\
\text { Availab } \\
\text { le }\end{array}$ & Women & $\begin{array}{l}\quad \text { Se } \\
\text { at } \\
\text { Avai } \\
\text { lable }\end{array}$ & $\begin{array}{l}\text { Wom } \\
\text { en }\end{array}$ & $\begin{array}{l}\quad \text { Seat } \\
\text { Availa } \\
\text { ble }\end{array}$ & $\begin{array}{l}\text { Wom } \\
\text { en }\end{array}$ & $\begin{array}{l}\text { Seat } \\
\text { Availa } \\
\text { ble }\end{array}$ & $\begin{array}{l}\text { Wom } \\
\text { en }\end{array}$ & $\begin{array}{l}\text { Seat } \\
\text { Availa } \\
\text { ble }\end{array}$ & $\begin{array}{l}\text { Wom } \\
\text { en }\end{array}$ \\
\hline President & 1 & 0 & 1 & 0 & 1 & 0 & 1 & 0 & 1 & 0 \\
\hline $\begin{array}{c}\text { Vice } \\
\text { President }\end{array}$ & 1 & 0 & 1 & 0 & 1 & 0 & 1 & 0 & 1 & 0 \\
\hline Senate & 109 & $3(2.8 \%)$ & 109 & $4(3.7 \%)$ & 109 & $8(7.3 \%)$ & 109 & $7(6.4 \%)$ & 109 & $8(6.4 \%)$ \\
\hline $\begin{array}{l}\text { House of } \\
\text { Reps }\end{array}$ & 360 & $12(3.3)$ & 360 & $21(5.8)$ & 360 & $23(6.4)$ & 360 & $26(7.2)$ & 360 & $19(5.3)$ \\
\hline Governors & 36 & 0 & 36 & 0 & 36 & 0 & 36 & 0 & 36 & 0 \\
\hline $\begin{array}{c}\text { Dep. } \\
\text { Governors }\end{array}$ & 36 & $1(2.8)$ & 36 & $2(5.5)$ & 36 & $6(16.7)$ & 36 & $3(8.3)$ & 36 & $4(1.1)$ \\
\hline SHA & 990 & $12(1.2)$ & 990 & $38(3.8)$ & 990 & $52(5.3)$ & 990 & $62(6.3)$ & 990 & - \\
\hline \begin{tabular}{l}
\multicolumn{1}{c}{ SHA } \\
Commitees \\
Chairperso \\
ns
\end{tabular} & 829 & $18(2.2)$ & 881 & $32(3.6)$ & 887 & $52(5.3)$ & 887 & - & - & - \\
\hline \begin{tabular}{l}
\multicolumn{1}{c}{ LGA } \\
Chairperso \\
ns
\end{tabular} & 710 & $9(1.2 \%)$ & 774 & $151.7 \%)$ & 740 & $27(3.6)$ & 740 & - & - & - \\
\hline Councilors & 8,810 & $\begin{array}{l}143(0.02 \\
\%)\end{array}$ & $\begin{array}{l}6,36 \\
8\end{array}$ & $\begin{array}{l}267(4.2 \\
\%)\end{array}$ & $8^{6,36}$ & $\begin{array}{l}235(3.7 \\
\%)\end{array}$ & 6,368 & - & - & - \\
\hline
\end{tabular}

Source: Akpan (2015) 


\section{Appointive positions}

Between 1999 and 2003, out of 130 federal boards of public corporations only 7 were women. Also, out of 47 cabinet ministers, only 7 were women. Just one woman was appointed as Director-General of a government regulatory agency. 2 women each were appointed Special Advisers and Senior Special Assistants, 6were made Special Assistants, and another 8 as Permanent Secretaries. In 2011 there was a slight improvement: 12 women were appointed as Ministers out of 42, while 4 (out of 20)were made Special Advisers.

In this present administration of Muhammadu Buhari, only 6 women were appointed as Ministers out of 30 . However, Amina Mohammed later quit following her appointment as the Deputy Secretary General of the United Nations, Kemi Adeosun was forced to resign, while Jummai Alhassan left voluntarily.

\section{Women's Political participation in Nupe Communities}

Literature on women's political participation in Nupe communities since the return of democracy in 1999 is very scanty. However, the records obtained from the Offices of the Independent National Electoral Commission (INEC) and the Niger State Independent Electoral Commission (NIEC) as well as the Niger State House of Assembly, indicates that women's political participation in Nupe communities has been abysmal. This is evident by the limited number of women that were known to have held political offices since the beginning of democracy in 1999. For example, only two women, Senator Zainab Kure and Honourable Habiba Lamido (out of a total of 629,237 that make up the population of women in the entire eight (8) Nupe-speaking Local Government Councils in Niger State according to the 2006 population census), have held elected positions since 1999. While Zainab Kure was elected Senator in 2007 and 2011, Habiba Lamido was elected member representing Bida South II state constituency in 1999.It is significant to note also that no woman has had the opportunity of being elected as a Local Government Council Chairperson or a Councilor since 1999 in the entire Nupe-speaking areas.

\section{THEORETICAL FRAMEWORK}

The study is anchored on the theoretical baseline of Liberal Feminism.To the Liberal feminists, what women want is what men want: to get an education, to make a decent living, to provide for one's family. They focus more on issues like equality in the workplace, in education, and political rights. While not denying that there may be biologically-based differences between men and women, liberal feminism does not support the argument that biologically-based differences are adequate justification for inequality, such as; the gap between men and women in terms of occupation of political offices and decision making positions, the wage gap between men and women, etc.

Generally, liberal feminists believe that "female subordination is rooted in a set of customary and legal constraints that block women's entrance to and success in the so-called public world" (Lewis et at, 2017). They strive for sexual equality via down-to-earth political and legal reforms. Nobody benefits from existing gender inequalities; both men and women are harmed because the potential of females and males alike is suppressed.

In Nigeria, followers of this theoretical orientation hold that the long established myths and even jokes that misrepresent or downgrade women should be abolished to allow room for a new and better socialization process in society which will not deny women their rightful place or position in society. The disciples of this theory are sensitive to the language, style and general attitudes of men towards women (Ogundipe-Leslie, 1984).

The Liberal feminist theory highlights the imbalanced political participation adequately, as it questions every aspect of power relations between men and women. Disparities in political participation are explained based on gender. It also gives suggestions on how women can improve the situation. In this respect, the theory is relevant in addressing the factors militating against women's political participation in the study area.The theory is appropriate in this study because first, it helps expound the reasons for women's lagging behind in political participation as opposed to their male counterparts;secondly, it helps analyze the existence of socio-cultural determinants, which established women's domain in the private sphere and limited participation of women in the public sphere by contextualizing their activities as a function of certain historical occurrences, hence proposes corrective mechanisms; and, by emphasizing consciousness then action, the liberal strand adopted by the study, helps to rethink the past with a possible solution, based on penetration of the society that is male dominated, a variance that is shaped by social environment rather than natural phenomenon.

\section{METHODOLOGY}

The broad aim of the study was to examine factors militating against women's political participation in selected Nupe-speakingcommunities in Niger State.The specific objectives were:

i. To determine the nature and extent of women's political participation in selected Nupe Communities in Niger State.

ii. To identify the factors hindering the participation of women in politics in selected Nupe Communities in Niger State.

iii. To ascertain the influence of these factors hindering women's political participation in selected Nupe Communities in Niger State.

iv. To recommend strategic policy measures towards improving women's political participation in Nupe Communities in Niger State and Nigeria in general.

Data was obtained through social survey (by means of the Questionnaire) and In-depth Interviews. The population of the study comprised adult respondents in the Nupe-speaking communities of Niger State. The study area was divided into cluster units based on the eight existing Local Government Areas (LGAs), namely: Agaie, Bida, Edati, Gbako, Katcha, 
Lapai, Lavun and Mokwa. Three LGAs - Bida, Lavun and Mokwa - were systematically selected eventually. Then, they were further clustered in terms of the existing electoral wards ( 37 wards in all). The sample was further stratified in terms of gender (70\% female, $30 \%$ male). 10 respondents were purposively selected from each ward and administered with the questionnaire.

The In-depth Interviewscomprised 30 respondents purposively selected. They involved 8 LGA Women Leaders, 8 LGA Electoral Officers, 8 LGA Party Chieftains, Zone A Women Leader (Niger South Senatorial District), and 5 women that have contested for political positions in the study area.

\section{FINDINGS AND RECOMMENDATIONS}

The major findings of the study are summarized below:

1. On the average,there was low level of political participation by women in the study area, particularly as pertained to seeking for elective positions. In the same vein, the study showed that men were more involved in politics and were more conscious of political activities than the womenfolk. Men registered more as members of political parties than women, who hardly bothered to join political parties, and this substantially limit their political participation except asmere voters, rather than candidates.

2. Interestingly, however, over the years there have been a steady increase in the number of women voters who came out to cast their votes during elections - sometimes (as in the 2011 and 2015 polls) as many as or even more than their male counterparts.

3. Chief among the causes militating against women's participation in politics in the area waspoor economic status of women. Lack of financial wherewithal makes it difficult for women to seek for elective office, because they could not affordthe huge campaign expenses, most of them being poor or of low incomes.

4. Socio-cultural factors constituteda huge challenge to women's participation in politics. Gender roles (very demanding and tasking household chores and other responsibilities in mainly complex role sets), lack of support from spouses, low level of education, male domination and religion (which injunctions are often deliberately misinterpreted or manipulated to denigrate anddegrade female politicians) were found to severely hinder women political participation in the area. Their subordinatestatus within the still powerful patriarchal system and a socialization process that tends to internalize, institutionalize and reinforce this subordination were also fingered.

5. Political factors, or what may be termed 'environmental/ecological factors,' also playeda prominent role in suppressing the participation of Nupe women in politics. These include a hostile political atmosphere that offers little or no encouragement(only token incentives) to women, lack of internal party democracy,unfriendly and even discriminatory electoral rules, etc. The political parties did not have the desirable mechanism and structures that could provide support and motivations for women to actively partake of politics. Also, the study found that men were generally cynical or even out-rightly disapproved of the ability and capacity of women to hold leadership positions.

6. Security issues were also cited; the argumentthat the political terrain was characterized by activities of dangerous armed thugsand hooligans whose presence scared away women.

7. Inexplicable reluctance of the male-dominated political establishment to appoint competent and capable women into positions of leadership, except an insignificant well-connected few.

8. If left unchecked, the factors identified above are likely to continue to hinder women participation in politics - particularly their willingness and readiness to seek for elective positions or get appointed to key government posts. The whole thing has huge and devastating psychological effects on them, often bordering on inferiority complex and even inertia to play any meaningful role in the political process.

Accordingly, the study recommends as follows:

1. Government,in conjunction with the mass media and other relevant stakeholders, should engage in a massive campaign against women subordination, discrimination and stigmatization in the society. In particular, there should also be an intensive sensitization onthe imperative of women playing a front-row role in politics. This can be done throughadvocacy involving traditional and community rulers, youth, women and opinion leaders, faith-based organizations, the civil society, etc

2. Economic empowerment strategies need to be introduced to improve lives of poor women and men. Accordingly, loan schemes with minimal interest rates should be made available for women to enable them embark on small and medium scale business enterprises. In addition, the Central Bank of Nigeria should mandate commercial and microfinance banks to remove the stringent regulations that make loans inaccessible for women. Other financial institutions should give special priority to women who seek loan for business.

3. The Nigerian government at all levels should abolish all laws, statutes, obnoxious customary practices and rituals that subordinate women to men. Government should consciously mainstream 
women's perspectives and issues in all policies, plans and programmes in public and private spheres.

4. Political parties should give women aspirants and candidates special concessions and waivers, and this should be institutionalized and provided in their constitutions. As part of deliberate efforts at inclusion, parties should have a certain proportion of women in all their decision making organs and processes.

5. Healthcareand child care centres as well as other social facilities should be established in our towns and villages to reduce the pressure of domestic responsibilities and chores on women. This may allow women have more time for participation in politics.

6. Special girl-child education programmes should be introduced, which target mandatory enrolment of all female children of school-going age.

7. As a matter of priority and urgency, Government must take steps to arrest and curb the activities of political thugs and gangsters.

\section{REFERENCES}

[1] Agbalajobi, D.T. (2010). "Women's Participation and the Political Process in Nigeria: Problems and Prospects."African Journal of Political Science and International Relations, 4(2), 075-082.

[2] Akinboye, S. (2004). “ Introduction: Paradox of Gender Equality in Nigeria." In: S. Akinboye (ed.), Paradox of Gender Equality in Nigerian Politics, Lagos: Concept Publications.

[3] Anifowose, R. (2004). "Women Political Participation in Nigeria: Problems and Prospects." In: S.O, Akinboye. (ed.) 2004, Paradox of Gender Equity in Nigerian Politics. Concepts Publication Limited, Lagos.

[4] Awofeso, O. and Odeyemi, T. I. (2014) "Gender and political participation in Nigeria: a Cultural Perspective," in Journal Research in Peace, Gender and Development (JRPGD), Vol. 4(6), pp. 104-110.

[5] Douglas, L. (2014). "Factors Impeding Political Participation and Representation of Women in Kenya,"Humanities and Social Sciences, 1(2), 173-181.

[6] Enemuo, F. C (1999). "Gender and Women Empowerment" in Anifowose, R. and Enemuo, F. C. (Eds) Elements of Politics, Lagos: Sam Iroanusi Publication.

[7] Falade, D.A. (2014). "Political Participation in Nigerian Democracy: A Study of Some Selected Local Government Areas in Ondo State, Nigeria,"Global Journal of Human Social science Research, 14 (8).

[8] Farzana, B. (2005). "Women's Political Participation: Issues and Challenges," Division for the Advancement of Women (DAW) Expert Group Meeting, Bangkok, Thailand, pp. 10-29.

[9] Galston, W.A. (2001). "Political Knowledge, Political Engagement, and Civic Education”, Annual Review of Political Science, 1(4), 217-234.

[10] Heywood, A. (2007). Politics, New York: Palgrave McMillan.

[11] Igbuzor, O. (2009). Challenges of Development in Nigeria, Lagos: Robitos Alliance Publishers.

[12] Igwe, O. (2002). Politics and Globe Dictionary, Enugu: Jamoe Enterprises.

[13] Jimoh, A. (2014). Enhancing Women's Representation in the Parliament. A Publication by the Civil Society Legislative Advocacy (CISLAC), Abuja.

[14] Lewis, P., Benschop, Y., and Simpson, R. (2017). "Postfeminism, Gender and Organization," Gender, Work \& Organization, 24, 213-225.
[15] Nebolisa, E. (2009). "Women and Politics. Peace \& Conflict Monitor," 13. Retrieved from http://search.ebscohost.com (AN 37584095).

[16] Ogbogu, C. O. (2011). "Gender Inequality in Academia: Evidences from Nigeria,'

[17] Contemporary Issues in Education Research, 4(9), 1-8.

[18] Ogundipe-Leslie, (1988). "Mobilizing the Mobilizers, Sex and Gender Problems in Nigeria Today," Paper Presented at the National Conference on Social Mobilization Held at the University of Jos, Nigeria, 25 - 30 January.

[19] Okafor, E. M. and Akokuwebe, M. E. (2015). "Women and Leadership in Nigeria: Challenges and Prospects,"Developing Country Studies, $5(4), 1-10$.

[20] Rai, S. M. (2005). "Equal Participation of Women and Men in Decision-Making Process, with Particular Emphasis on Political Participation and Leadership," Background Paper Prepared for the Expert Group Meeting of the Division for the Advancement of Women (DAW), United Nations held 24-27 October, 2005 in Addis Ababa.

[21] Udegbe, B. (1998) "Gender and Leadership Lineages and Reality," Faculty Lecture at the University of Ibadan, Ibadan: Vintage Publication,

[22] Vissandjes, B. Abdool S. Apale, A. and Dupere, S. (2008). "Women's Political Participation in Rural India: Discerning Discrepancies Through a Gender Long." Indian Journal of Gender Studies. Vol. 13(3) 426-44. 